\title{
Efficacy and safety of enoxaparin versus unfractionated heparin during percutaneous coronary intervention: systematic review and meta-analysis
}

\author{
@() $\Theta$ OPEN ACCESS
}

\begin{abstract}
Johanne Silvain associate professor ${ }^{1}$, Farzin Beygui professor ${ }^{1}$, Olivier Barthélémy senior consultant ${ }^{1}$, Charles Pollack Jr professor ${ }^{2}$, Marc Cohen professor ${ }^{3}$, Uwe Zeymer professor ${ }^{4}$, Kurt Huber professor $^{5}$, Patrick Goldstein professor ${ }^{6}$, Guillaume Cayla associate professor ${ }^{7}$, Jean-Philippe Collet professor $^{1}$, Eric Vicaut professor ${ }^{8}$, Gilles Montalescot professor ${ }^{1}$

${ }^{1}$ Institut de Cardiologie, Bureau 2-236, Centre Hospitalier Universitaire Pitié-Salpêtrière, 47 Boulevard de l'Hopital, 75013 Paris, France; ${ }^{2}$ Department of Emergency Medicine, Pennsylvania Hospital, University of Pennsylvania, Philadelphia, PA, USA; ${ }^{3}$ Division of Cardiology, Newark Beth Israel Medical Center, Newark, NJ, USA; ${ }^{4}$ Herzzentrum Klinikum Ludwigshafen, Medizinische Klinik B, Ludwigshafen, Germany; ${ }^{5}$ Department of Internal Medicine, Cardiology and Emergency Medicine, Wilhelminen Hospital, Vienna, Austria; ${ }^{6}$ SAMU, CHRU Lille, France; ${ }^{7}$ Cardiology Department, Centre Hospitalier Carémeau, Nîmes, France; ${ }^{8}$ Unité de Recherche Clinique, Lariboisière Hospital, Paris, France
\end{abstract}

\begin{abstract}
Objective To determine the efficacy and safety of enoxaparin compared with unfractionated heparin during percutaneous coronary intervention. Design Systematic review and meta-analysis.

Data sources Medline and Cochrane database of systematic reviews, January 1996 to May 2011.

Study selection Randomised and non-randomised studies comparing enoxaparin with unfractionated heparin during percutaneous coronary intervention and reporting on both mortality (efficacy end point) and major bleeding (safety end point) outcomes.

Data extraction Sample size, characteristics, and outcomes, extracted independently and analysed.

Data synthesis 23 trials representing 30966 patients were identified, including 10243 patients (33.1\%) undergoing primary percutaneous coronary intervention for ST elevation myocardial infarction, 8750 (28.2\%) undergoing secondary percutaneous coronary intervention after fibrinolysis, and 11973 (38.7\%) with non-ST elevation acute coronary syndrome or stable patients scheduled for percutaneous coronary intervention. A total of 13943 patients $(45.0 \%)$ received enoxaparin and 17023 (55.0\%) unfractionated heparin. Enoxaparin was associated with significant reductions in death (relative risk $0.66,95 \%$ confidence interval 0.57 to $0.76 ; \mathrm{P}<0.001)$, the composite of death or myocardial infarction $(0.68,0.57$ to $0.81 ; P<0.001)$, and complications of myocardial infarction
\end{abstract}

$(0.75,0.6$ to $0.85 ; \mathrm{P}<0.001)$, and a reduction in incidence of major bleeding $(0.80,0.68$ to $0.95 ; P=0.009)$. In patients who underwent primary percutaneous coronary intervention, the reduction in death $(0.52,0.42$ to $0.64 ; \mathrm{P}<0.001$ ) was particularly significant and associated with a reduction in major bleeding $(0.72,0.56$ to $0.93 ; P=0.01)$.

Conclusion Enoxaparin seems to be superior to unfractionated heparin in reducing mortality and bleeding outcomes during percutaneous coronary intervention and particularly in patients undergoing primary percutaneous coronary intervention for ST elevation myocardial infarction.

\section{Introduction}

The use of unfractionated heparin during percutaneous coronary intervention is limited by its unpredictable effect, the need for close monitoring, and the uncertainty around optimal levels of activated clotting time..$^{1-4}$ Moreover, the drug exhibits prothrombotic properties related to platelet activation, poor control of von Willebrand factor release, and rebound of thrombin generation after discontinuation. ${ }^{56}$ Despite these limitations and the absence of relevant randomised placebo controlled trials, anticoagulation during elective and primary percutaneous coronary intervention has traditionally been supported by unfractionated heparin, based largely on historical practice. The current updated guidelines for anticoagulation in patients requiring percutaneous coronary intervention for ST 
segment elevation myocardial infarction produced by the American College of Cardiology, American Heart Association, and Society of Cardiac Angiography and Intervention as well as guidelines from the Task Force on Myocardial Revascularization of the European Society of Cardiology continue to afford unfractionated heparin a class 1 recommendation for this indication, despite limited supporting evidence (level of evidence C). ${ }^{78}$

Enoxaparin is the leading low molecular weight heparin with the largest volume of published information on use in the setting of percutaneous coronary intervention. It provides predictable anticoagulation without the need for monitoring ${ }^{9}{ }^{10}$ and it can be administered predominantly by subcutaneous injection, as in the management of non-ST elevation acute coronary syndromes and ST elevation myocardial infarction treated with thrombolysis, in both cases with a scheduled invasive strategy (American College of Cardiology and American Heart Association class IIa and I, respectively). Enoxaparin can also be used with intravenous injections for immediate anticoagulation in patients undergoing primary percutaneous coronary intervention or elective percutaneous coronary intervention, as shown recently in several randomised studies. ${ }^{11-14}$ Although studies have evaluated enoxaparin during percutaneous coronary intervention in several clinical settings, ${ }^{15-33}$ none was powered for mortality.

We pooled the data from all the studies that compared enoxaparin with unfractionated heparin during percutaneous coronary intervention to gain sufficient power to evaluate potential differences in mortality and safety.

\section{Methods}

Two researchers (JS and GM) searched PubMed and the Cochrane database of systematic reviews from January 1996 to May 2011 using the search terms "enoxaparin", "unfractionated heparin", "angioplasty", and "percutaneous coronary intervention". In addition, we contacted experts in the specialty and reviewed abstracts from selected major cardiology scientific meetings (American Heart Association, American College of Cardiology, European Society of Cardiology, and Transcatheter Cardiovascular Therapeutics). The meta-analysis included cohort studies and clinical trials that compared the efficacy and safety of enoxaparin with unfractionated heparin among patients undergoing primary, secondary (post-fibrinolysis), or scheduled percutaneous coronary intervention according to a predefined protocol. We restricted our analysis to trials that met all of the following inclusion criteria: patients with coronary heart disease undergoing percutaneous coronary intervention, considering the whole study population or at least a predominant subset of this population; a control group using unfractionated heparin for comparison with enoxaparin; and publications reporting data at least on mortality and major bleeding. To focus on the direct comparison of enoxaparin with unfractionated heparin, we excluded studies that used a low molecular weight heparin other than enoxaparin, with the exception of one study in which other low molecular weight heparins were used in a few of the patients. ${ }^{34}$

A total of 229 studies were identified as potentially relevant and were screened for inclusion. Of the 34 studies that fulfilled the inclusion criteria and were screened in detailed, we subsequently excluded 11 because they did not include data on efficacy outcomes ${ }^{35}$ did not include data on the percutaneous coronary intervention subgroup, ${ }^{36-41}$ published details of the percutaneous coronary intervention subgroup in a separate article, ${ }^{42}{ }^{43}$ or studied a low molecular weight heparin other than enoxaparin. ${ }^{44}{ }^{45}$ From the 23 studies remaining for the analysis, two reviewers (JS and OB) independently extracted outcome data and recorded the information on a standardised case report form. When available we extracted the following data from each trial: year of publication, trial design, population characteristics, number of patients (per group), dose and mode of enoxaparin administered, dose of unfractionated heparin, use of antiplatelet drugs (aspirin, thienopyridine, and platelet glycoprotein IIb/IIIa inhibitors), duration of follow-up, efficacy end points, and safety end points (see web extra table).

\section{Assessment and reporting risk of bias in included studies}

Two independent reviewers determined the quality score of non-randomised studies and subanalysis and retrospective analysis of randomised controlled trials according to the Newcastle-Ottawa scale for cohort studies (www.ohri.ca/ programs/clinical_epidemiology/oxford.htm). We also carried out a validity assessment according to the Cochrane Collaboration's tool for assessing risk of bias. Randomised clinical trials were graded based on sequence generation, allocation concealment, blinding, incomplete outcome data, selective outcome reporting, and other sources of bias. For each trial we summarised the global assessment of risk of bias as low, unclear, or high. We entered data into a centralised database for analysis and resolved discrepancies by consensus of two authors (JS and OB). If additional data or clarification was necessary we contacted the study authors. When necessary, research associates with the relevant language helped to interpret non-English manuscripts. ${ }^{24}$

\section{Endpoint definitions}

The main objective of this study was to evaluate the impact of enoxaparin and unfractionated heparin on mortality (main efficacy end point) and major bleeding (main safety end point) during percutaneous coronary intervention. We considered all cause mortality except in studies where only cardiovascular mortality was reported. The bleeding definitions used for this analysis were those corresponding to the main safety end point of each study (see web extra table). Other efficacy end points analysed were the composite ischaemic end point of death or myocardial infarction and complications of myocardial infarction (or post-procedure myocardial infarction when this was the only reported complication) as defined in each study. Major bleeding was the main safety end point, although we also collected and analysed data on minor bleeding. We considered all end points at the longest follow-up available in each study. Firstly, we carried out a global meta-analysis of all the studies, including all patients after percutaneous coronary intervention regardless of the clinical presentation. Secondly, we carried out a meta-analysis for the same end points, restricting the analyses to predefined types of percutaneous coronary intervention: primary, secondary (post-fibrinolysis), and scheduled (patients with non-ST elevation acute coronary syndromes or stable patients).

\section{Statistical analysis}

From each publication we obtained the raw numbers of patients experiencing the outcomes of interest among all patients in each treatment group. We obtained the common effect calculation by analysis of all patients. Using a random model we carried out several analyses to obtain a global estimation of the treatment effect and to minimise heterogeneity between groups. We used the EasyMa software (Department of Clinical 
Pharmacology and Biostatistic, EA643, university hospital of Lyon, France) to calculate relative risks with $95 \%$ confidence intervals. ${ }^{46}$ An $\alpha$ risk of $5 \%$ was used. Finally, the number of patients needed to treat (NNT) to avoid one event was calculated using the overall weighted risk difference: $\mathrm{NNT}=1 /$ (absolute risk difference).

\section{Confirmatory evaluation of potential bias}

We carried out a confirmatory analysis using the "meta" package of $\mathrm{R}$ software ( $\mathrm{R}$ version 2.13.0, R Foundation for Statistical Computing) and arcsine transformation. This analysis accounts for heterogeneity, particularly when effect sizes are small and heterogeneity is high, and allows inclusion of trials with zero events in each arm.

\section{Subgroup analysis and investigation of heterogeneity}

Although the random effect model accommodated variability among studies, we examined the extent of heterogeneity in the individual trials. We used the Q Cochran test to look for heterogeneity between groups, with heterogeneity tests set at $0.1{ }^{47}$ Potential small study bias or publication bias (that is, the likelihood of small yet nominally significant studies being published selectively) was examined by visual inspection of constructed funnel plots and analytically using Egger's test. ${ }^{48}$ Egger's method plots linearly the standard normal deviate (natural logarithm of relative risk/standard error (SE) of relative risk) and precision (1/SE of relative risk) as independent variables, with test results based on the $\mathrm{P}$ value of the regression constant.

\section{Sensitivity analysis}

We carried out a sensitivity analysis by removing each study in turn from the overall data to evaluate the influence of a single study on the pooled analysis and by restricting the meta-analysis to several subgroups: patients with ST elevation myocardial infarction undergoing percutaneous coronary intervention (primary or secondary), published (full length) studies, small ( $<500$ patients) versus large studies ( $\geq 500$ patients), intravenous versus subcutaneous enoxaparin, and high quality (randomised controlled trials) or low quality studies (registry based).

\section{Results}

Twenty three trials, totalling 30966 patients, met the inclusion criteria (fig $1 \Downarrow$ ). Twelve randomised controlled trials and 11 non-randomised trials (including four subanalyses of randomised controlled trials) compared enoxaparin with unfractionated heparin during percutaneous coronary intervention. The average follow-up of the studies was 2.4 months, but most ( $\mathrm{n}=19)$ had only short term follow-up (in hospital or at 30 days). A total of 13943 patients $(45.0 \%)$ received enoxaparin and $17023(55.0 \%)$ unfractionated heparin. In seven trials, totalling 10243 patients $(33.1 \%)$, primary percutaneous coronary intervention was carried out for ST elevation myocardial infarction; in three trials, totalling 8750 patients $(28.2 \%)$, percutaneous coronary intervention was carried out after initial reperfusion with lytics; and in 13 trials, totalling 11973 patients (38.7\%), percutaneous coronary intervention was carried out in an elective setting. In 15 of these trials, enoxaparin was used as an intravenous bolus just before percutaneous coronary intervention; at a low dose $(0.5 \mathrm{mg} / \mathrm{kg})$ in four studies and at a higher dose $(0.75 \mathrm{mg} / \mathrm{kg}$ or $1 \mathrm{mg} / \mathrm{kg}$ ) in 12 studies (including the $0.75 \mathrm{mg} / \mathrm{kg}$ arm of the STEEPLE trial). In six trials, patients underwent percutaneous coronary intervention under a regimen of enoxaparin administered subcutaneously, and in two trial ${ }^{20} 33$ no mention was made of the enoxaparin dose or mode in which it was administered. The dose range for unfractionated heparin was 60 to $100 \mathrm{IU} / \mathrm{kg}$ bolus according to the concomitant use of platelet glycoprotein IIb/IIIa inhibitors or not, with further adjustments based on measurement of activated clotting time. Table $1 \Downarrow$ outlines the details of the trials, the settings of the percutaneous coronary intervention, and length of follow-up (see web extra table for anticoagulation protocols, concomitant use of antiplatelet therapies, and major baseline characteristics of each study). Within each randomised trial, the baseline characteristics of patients treated with enoxaparin or with unfractionated heparin were similar, but some of the main characteristics in the registry based studies differed (see web extra table).

\section{Summary of end points}

Figure $2 \Downarrow$ summarises all studied end points for the total population of the meta-analysis, as well as the subgroup of patients undergoing primary percutaneous coronary intervention. The Cochrane $\mathrm{P}$ value for heterogeneity is included.

\section{Mortality}

In the overall cohort of patients $(n=30966)$, enoxaparin was associated with a $34 \%$ relative risk reduction $(0.66,95 \%$ confidence interval 0.58 to $0.77 ; \mathrm{P}<0.001)$ and a $1.66 \%$ absolute risk reduction of mortality $(\mathrm{NNT}=60$; fig $3 \Downarrow$ ). Heterogeneity between trials was not significant $(\mathrm{P}=0.46)$ and evidence of publication bias using the funnel plot and Egger's regression test was lacking $(\mathrm{P}=0.82)$. In the higher risk group of patients with ST elevation myocardial infarction undergoing primary percutaneous coronary intervention $(n=10243)$, enoxaparin was associated with a significant $48 \%$ relative risk reduction in mortality (3.12\% enoxaparin $v 6.03 \%$ unfractionated heparin) and a $2.91 \%$ absolute relative risk reduction $(\mathrm{P}<0.001$; $\mathrm{NNT}=34)$. Heterogeneity between trials was not significant $(\mathrm{P}=0.53)$ and evidence of publication bias in the primary percutaneous coronary intervention subgroup was lacking $(\mathrm{P}=0.90)$. In the smaller and lower risk group of patients with non-ST elevation acute coronary syndromes and stable coronary artery disease undergoing scheduled percutaneous coronary intervention (relative weight $12.5 \%$; mortality rate $0.88 \%$ ) mortality rates did not differ significantly between the enoxaparin and unfractionated heparin cohorts, with a trend towards a reduction in mortality with enoxaparin.

\section{Safety outcomes}

In the overall cohort of patients with reported major bleeding $(n=30775)$, enoxaparin was associated with a $20 \%$ relative risk reduction $(0.80,95 \%$ confidence interval 0.67 to $0.95 ; \mathrm{P}=0.009)$ and an absolute risk reduction of $1.20 \%$ (NNT=83; fig $4 \Downarrow$ ). Heterogeneity between trials was not significant $(\mathrm{P}=0.58)$ and evidence of publication bias was lacking. The reduction in major bleeding seemed to be greater in patients with ST elevation myocardial infarction undergoing primary percutaneous coronary intervention, with enoxaparin treatment compared with unfractionated heparin treatment resulting in relative and absolute risk reductions of $28 \%$ and $1.9 \%$, respectively $(\mathrm{NNT}=53), \mathrm{P}=0.01$.

Although the incidence of minor bleeding was numerically lower in patients treated with enoxaparin than with unfractionated heparin, this difference was not significant in the overall percutaneous coronary intervention cohort or in the setting of primary percutaneous coronary intervention (fig 2). 


\section{Ischaemic end points}

Compared with unfractionated heparin, enoxaparin was associated with a $32 \%$ relative risk reduction and $2.01 \%$ absolute risk reduction of death or myocardial infarction (relative risk $0.68,95 \%$ confidence interval 0.57 to $0.81 ; \mathrm{P}<0.001$, NNT $=50$; see web extra figure 1). Similarly, enoxaparin was associated with a significant $25 \%$ relative risk reduction and $1.52 \%$ absolute risk reduction in complications of myocardial infarction $(0.75$, 0.66 to $0.85 ; \mathrm{P}<0.001$; NNT=66; see web extra figure 2 ). Heterogeneity between trials for these two composite end points was not significant $(\mathrm{P}=0.42$ and $\mathrm{P}=0.55$, respectively) and evidence of publication bias using the funnel plot was not found. The magnitude of the enoxaparin effect was largest in patients with ST elevation myocardial infarction undergoing primary percutaneous coronary intervention, with a $44 \%$ relative risk reduction and a $3.6 \%$ absolute risk reduction of death or myocardial infarction $(0.56,0.42$ to 0.76 ; $\mathrm{NNT}=28 ; \mathrm{P}<0.001)$, with a consistent significant reduction of complications of myocardial infarction compared with unfractionated heparin $(0.76,0.60$ to $0.96 ; \mathrm{P}=0.022$; see web extra figure 1$)$.

\section{Sensitivity and subgroups analyses}

A series of sensitivity analyses confirmed the same directionality for the primary efficacy end point (mortality) and the primary safety end point (major bleeding, tables $2 \Downarrow$ and $3 \Downarrow$ ). None of the studies individually affected the overall results either for mortality or for major bleeding. The reduction in mortality associated with enoxaparin was consistent across all subgroups, with the single exception of the subgroup of small sized studies ( $<500$ patients), which showed a reduction of similar magnitude that did not reach significance (relative risk $0.59,95 \%$ confidence interval 0.20 to $1.78 ; \mathrm{P}=0.35$ ). No subgroup analyses showed heterogeneity, and the superiority of enoxaparin on mortality was significant in both randomised controlled studies $(n=16)$ and registry based studies $(n=7)$. Results were consistent for major bleeding across all subgroups except for route of administered enoxaparin. In the subgroup of studies (14 studies, 10260 patients) using intravenous enoxaparin, major bleeding was reduced by $34 \%$ compared with unfractionated heparin (0.66, 0.52 to $0.83 ; \mathrm{P}<0.001$, $\mathrm{P}$ for heterogeneity 0.9 ; absolute risk reduction $1.52 \%$; NNT=66). This favourable effect was not observed in the subgroup of studies that used subcutaneous enoxaparin (six studies, 16527 patients), with no difference between the two anticoagulants $(1.04,0.80$ to $1.35, \mathrm{P}=0.7, \mathrm{P}$ for heterogeneity 0.4 ). Finally, the arcsine test for binary outcomes confirmed the results of the primary additive summary models for all end points.

\section{Discussion}

In this meta-analysis, enoxaparin was superior to unfractionated heparin in reducing mortality and bleeding outcomes during percutaneous coronary intervention, particularly in patients undergoing primary percutaneous coronary intervention for ST elevation myocardial infarction. Since early 2000 data have accumulated on enoxaparin in varied percutaneous coronary intervention settings. This current meta-analysis, with information on more than 30000 patients, showed a $34 \%$ statistically significant reduction in mortality $(1.66 \%$ absolute risk reduction) in patients receiving enoxaparin during percutaneous coronary intervention compared with unfractionated heparin. This survival benefit is supported by concomitant reductions in both ischaemic and major bleeding complications. All sensitivity analyses of mortality confirmed a genuine difference between the two drugs. Subgroup analyses suggested that the benefits on mortality and ischaemic complications were largely driven by the superiority measured in patients undergoing primary percutaneous coronary intervention for ST elevation myocardial infarction, whereas the better safety outcomes might be driven by the intravenous (versus subcutaneous) use of enoxaparin.

This meta-analysis confirms the results recently reported in the ATOLL (Acute ST-elevation myocardial infarction Treated with primary angioplasty and intravenous enoxaparin Or unfractionated heparin to Lower ischemic and bleeding events at short- and Long-term follow-up) randomised trial. ${ }^{14}$ Compared with unfractionated heparin, intravenous enoxaparin at a dose of $0.5 \mathrm{mg} / \mathrm{kg}$ reduced death or resuscitated cardiac death in patients undergoing primary percutaneous coronary intervention by $42 \%(\mathrm{P}=0.049)$ and death or myocardial infarction by $37 \%$ $(\mathrm{P}=0.02) .{ }^{14}$ Although the $40 \%$ relative risk reduction in all cause mortality associated with enoxaparin in ATOLL was not significant $(\mathrm{P}=0.08)$ owing to lack of power, it is consistent with the $38 \%$ reduction in mortality found in the group with ST elevation myocardial infarction in the current meta-analysis $(\mathrm{P}<0.001)$, and more specifically with the $48 \%$ reduction of mortality in patients undergoing primary percutaneous coronary intervention $(\mathrm{P}<0.001)$. The survival benefit associated with enoxaparin was present in both risk of bias subgroups in our meta-analysis; in low risk of bias studies (randomised trials and retrospective analysis of randomised trials) and in those showing higher risk of bias (non-randomised studies).

This reduction in mortality is likely to be related to the favourable effects of enoxaparin in the prevention of ischaemic complications, which were also shown in this meta-analysis. Consistent reductions in ischaemic end points were observed in the overall analysis as well as in the five largest randomised studies, ${ }^{13} 14303542$ which together represented two thirds of the weight of ischaemic events in our meta-analysis. In comparison with unfractionated heparin, enoxaparin has been shown to be more stable and have more predictable pharmacokinetics, ${ }^{1}$ providing an optimal level of anticoagulation at the time of the procedure in more than $90 \%$ of patients, by whatever route the drug is administered..$^{99-51}$ These optimal levels of anticoagulation have also been related to better ischaemic and survival outcomes. ${ }^{10}$ Moreover, additional endothelial and anti-inflammatory properties of enoxaparin ${ }^{6}$ may play an additional part in the prevention of ischaemic complications of acute coronary syndrome.

Improved safety might also contribute to the reduction in mortality rates. Previous studies have shown that bleeding and red blood cell transfusion have deleterious effects ${ }^{52}$ and have an effect on ischaemic outcomes as well as on mortality. ${ }^{53}$ Therefore the $20 \%$ reduction in major bleeding associated with enoxaparin might also have affected ischaemic and mortality outcomes. This result is consistent among all subgroups, with the exception of studies in which subcutaneous enoxaparin was used in comparison with unfractionated heparin, when no difference was seen. It seems that the reduction in major bleeding was mostly observed with intravenous enoxaparin, but the $\mathrm{P}$ value for interaction was not significant probably because of the heterogeneity in risk levels of populations in the two subgroups (subcutaneous versus intravenous). Indeed, the intravenous route provides immediate anticoagulation, with rapid clearance, ${ }^{49}$ avoiding exposure to prolonged anticoagulation after percutaneous coronary intervention, and in this study was associated with a $34 \%$ reduction in major bleeding (absolute risk reduction 1.52\%) compared with unfractionated heparin. Therefore this meta-analysis confirms the benefit of enoxaparin measured in the individual randomised 
STEEPLE ${ }^{1}$ (elective angioplasty) and ATOLL ${ }^{14}$ (primary angioplasty) studies, with enough power to show a reduction in mortality. Patients with ST elevation myocardial infarction obviously gain a large benefit from enoxaparin on ischaemic end points and mortality. Although favourable, the magnitude of these effects seems less important in other clinical situations.

\section{Comparisons with other reviews}

Other new anticoagulants have been compared with unfractionated heparin in the setting of percutaneous coronary intervention. Bivalirudin alone compared with unfractionated heparin plus glycoprotein IIb/IIIa inhibitors has consistently shown improved safety in percutaneous coronary intervention, associated with a reduction in mortality in one trial. ${ }^{54-57} \mathrm{Head}$ to head comparisons of unfractionated heparin alone in percutaneous coronary intervention have also suggested a better safety profile of bivalirudin, but without significant advantage on the net clinical benefit or mortality. ${ }^{58-60}$ Finally, a recent meta-analysis of nine trials, totalling almost 30000 patients, confirmed the reduction in major bleeding complications from use of bivalirudin compared with unfractionated heparin, but failed to show any benefit on mortality, whereas a trend for higher risk of myocardial infarction was noted. ${ }^{61}$ In contrast with this, a meta-analysis of nine studies, totalling 16286 patients, comparing low molecular weight heparin with unfractionated heparin in the setting of percutaneous coronary intervention for ST elevation myocardial infarction reported a reduction in both mortality and major bleeding consistent with our findings. ${ }^{62}$

An alternative anticoagulant, the synthetic factor Xa inhibitor fondaparinux, has been tested in acute coronary syndromes. ${ }^{63}$ Results were not favourable in patients with ST elevation myocardial infarction undergoing primary percutaneous coronary intervention ${ }^{64}$ and the drug has been tested only sparingly in elective percutaneous coronary intervention. ${ }^{65} \mathrm{~A}$ significant increase in catheter related thrombosis with fondaparinux prompted guidelines committees on both sides of the Atlantic to recommend unfractionated heparin as adjunctive treatment at the time of percutaneous coronary intervention. The recent results of the randomised Fondaparinux Trial With Unfractionated Heparin During Revascularization in Acute Coronary Syndromes (FUTURA) suggest that a standard unfractionated heparin dose of $85 \mathrm{IU} / \mathrm{kg}$ bolus, with an additional bolus if needed to achieve activated clotting time of 300 to 350 seconds, is preferable to a lower dose in patients previously treated with subcutaneous fondaparinux. ${ }^{3}$ In a pooled analysis of 19085 patients with acute coronary syndrome invasively managed, fondaparinux reduced major bleeding compared with a heparin based strategy, with similar rates of ischaemic events and no reduction in mortality. ${ }^{66}$

\section{Strengths and limitations of this meta-analysis}

Our meta-analysis has limitations and was not carried out on individual patients' data, which if possible would have strengthened the results, especially for subgroup analyses. Although differences in trial designs and definitions should be considered when interpreting the overall results, mortality is a hard end point not affected by study definitions. Duration and dose of study drugs also differed between trials, as did the use of concomitant treatments and types of revascularisation. Of note, many of the non-randomised studies were not pure head to head comparisons of the two anticoagulants. However, the absence of heterogeneity in the overall analysis and the sensitivity and subgroup analyses all showing consistent reductions in mortality, suggest that the results are robust. Regarding safety, it seems that the intravenous route for administering enoxaparin drives the reduction in major bleeding, confirming previous information from randomised trials. ${ }^{11} 1467$ Duration of anticoagulation is a possible confounder for this problem, although this information is usually not available in published data.

\section{Meaning of the study and implications for policymakers}

The profound reduction in mortality found in this meta-analysis could be explained by the additional reductions of serious ischaemic events and major bleeding. The global reduction in ischaemic events and mortality was driven by the major effect observed in the setting of primary percutaneous coronary intervention for ST elevation myocardial infarction and is in line with the results of the ATOLL randomised trial. ${ }^{14}$ This effect was obtained from anticoagulation using intravenous enoxaparin and the favourable pharmacodynamic profile of the $0.5 \mathrm{mg} / \mathrm{kg}$ dose. A similar benefit on mortality has been seen recently in other studies of ST elevation myocardial infarction using bivalirudin $^{56}$ or radial access. ${ }^{68}{ }^{69}$ In lower risk populations the same interventions did not reduce mortality. ${ }^{15469}$ The results of this meta-analysis should influence the next guidelines dealing with anticoagulation in percutaneous coronary intervention or in ST elevation myocardial infarction. The superiority of enoxaparin over unfractionated heparin is now well documented in the setting of percutaneous coronary intervention, by randomised controlled trials, registry based studies, and this meta-analysis, building the case for an update of current guidelines on anticoagulation. This is particularly true for primary percutaneous coronary intervention, where the benefit is most striking.

\section{Unanswered questions and future research}

Two new anticoagulants (bivalirudin and enoxaparin) have proved to be superior to unfractionated heparin during percutaneous coronary intervention, particularly in patients with ST elevation myocardial infarction undergoing primary percutaneous coronary intervention. A head to head comparison between intravenous enoxaparin and intravenous bivalirudin is needed in the setting of primary percutaneous coronary intervention using contemporary techniques (radial access, last generation of stent, and thromboaspiration) and new antiplatelet agents such as prasugrel or ticagrelor.

\section{Conclusions}

During percutaneous coronary intervention, enoxaparin seems to be superior to unfractionated heparin in reducing all cause mortality and ischaemic and bleeding end points. This superiority was particularly evident in patients with ST elevation myocardial infarction undergoing primary percutaneous coronary intervention. Given the relatively low cost of enoxaparin (and its wide availability), this seems to be an attractive strategy to improve outcomes in the large number of patients undergoing percutaneous coronary intervention worldwide.

Contributors: JS, OB, and GM designed the study; acquired, analysed, and interpreted the data; and revised the manuscript. JS, OB, FB, CP, $\mathrm{MC}, \mathrm{KH}, \mathrm{UZ}, \mathrm{GC}, \mathrm{J}-\mathrm{PC}$, and EV helped implement the study and made critical revision of the manuscript. JS did the statistical analysis, which was reviewed by OB, EV, and FB. JS wrote the first draft and submitted the final version of the manuscript under the supervision of GM. All 


\section{What is already known on this topic}

Enoxaparin has a more stable and predictable anticoagulant effect than unfractionated heparin, which requires tight monitoring and dose adjustment

In randomised studies, intravenous enoxaparin $0.5 \mathrm{mg} / \mathrm{kg}$ was superior to unfractionated heparin in elective percutaneous coronary intervention (reduction of bleeding) and primary percutaneous coronary intervention (reduction of ischaemic events)

\section{What this study adds}

Enoxaparin use during percutaneous coronary intervention reduced mortality by $34 \%$ (absolute risk reduction $1.66 \%$ ) compared with unfractionated heparin

The mortality benefit was particularly noticeable in patients with ST elevation myocardial infarction undergoing primary percutaneous coronary intervention

This survival benefit is supported by concomitant reductions in both ischaemic and major bleeding complications

authors have seen the final submitted manuscript and agree with its contents. JS and GM are the guarantors.

Funding: This study was led by the ACTION Study group (Academic Research Organization www.action-coeur.org) with no specific funding Competing interests: All authors have completed the ICMJE uniform disclosure form at www.icmje.org/coi_disclosure.pdf (available on request from the corresponding author) and declare: no support from any organisation for the submitted work; the following financial relationships or activities: GC has received a research grant from la Fédération Française de Cardiologie; consultant fees from Abbott Vascular, AstraZeneca, CLS Behring, Daiichi Sankyo, Eli Lilly; lecture fees from Abbott Vascular, AstraZeneca, Biotronik, CLS Behring, Daiichi Sankyo, Eli Lilly, and Iroko Cardio. MC has received grant support and speaker honorariums from Sanofi-Aventis, Bristol-Myers Squibb, and Merck. J-PC has received research grants from Bristol-Myers Squibb, Sanofi-Aventis, Eli Lilly, Guerbet Medical, Medtronic, Boston Scientific, Cordis, Stago, Fondation de France, INSERM, Fédération Française de Cardiologie, and Société Française de Cardiologie; consulting fees from Sanofi-Aventis, Eli Lilly, and Bristol-Myers Squibb; and lecture fees from Bristol-Myers Squibb, Sanofi-Aventis, Eli Lilly, and AstraZeneca. $P G$ has received consulting or board fees and lecture fees from AstraZeneca, Boehringer Ingelheim, Daiichi-Sankyo, Eli-Lilly, Sanofi-Aventis, and The Medicines Company. $\mathrm{KH}$ has received lecture fees from AstraZeneca, Bayer, BMS, Boehringer Ingelheim, Daiichi Sankyo, Eli Lilly, Pfizer, Sanofi-Aventis, Schering-Plough, and The Medicines Company. GM has received support from Abbott Vascular, Boston Scientific, Cordis, Eli Lilly, Fédération Française de Cardiologie, Fondation de France, Guerbet Medical, INSERM, ITC Edison, Medtronic, Pfizer, Sanofi-Aventis, Société Française de Cardiologie, and Stago; consulting or board fees and lecture fees from AstraZeneca, Bayer, Boehringer Ingelheim, Cardiovascular Research Foundation, Cleveland Clinic Research Foundation, Daiichi-Sankyo, Duke Institute, Eli Lilly, Europa, Lead-up, GlaxoSmithKline, Institut de Cardiologie de Montreal, Menarini, Nanospheres, Novartis, Pfizer, Portola, Sanofi-Aventis, The Medicines Company, and TIMI study group. CP has received research grants from Sanofi-Aventis and GlaxoSmithKline, and consulting fees from Sanofi-Aventis, and BristolMyersSquibb. JS has received research grants from Sanofi-Aventis, Daiichi-Sankyo, Eli Lilly, Brahms, INSERM, Fédération Française de Cardiologie, and Société Française de Cardiologie; consulting fees from Daiichi-Sankyo and Eli Lilly; and speaker honorariums from AstraZeneca, Daiichi Sankyo, Eli Lilly, Iroko Cardio, and Servier. EV has received consulting fees and lecture fees from Abbott, Amgen, Eli Lilly, Pfizer, Sanofi-Aventis, and Servier. UZ has received research grants and speaker honorariums from BMS, Eli Lilly, and Sanofi-Aventis; and consulting and lecture fees from AstraZeneca, Bayer, Boehringer Ingelheim, Daiichi Sankyo, Portola, and The Medicines Company; no other relationships or activities that could appear to have influenced the submitted work.

Ethical approval: Not required.

Data sharing: The dataset, statistical code, and review protocol are available from the corresponding at gilles.montalescot@psl.aphp.fr.
Montalescot G, Cohen M, Salette G, Desmet WJ, Macaya C, Aylward PE, et al. Impact of anticoagulation levels on outcomes in patients undergoing elective percutaneous coronary intervention: insights from the STEEPLE trial. Eur Heart J 2008;29:462-71.

2 Schulz S, Mehilli J, Neumann FJ, Schuster T, Massberg S, Valina C, et al. ISAR-REACT 3A: a study of reduced dose of unfractionated heparin in biomarker negative patients undergoing percutaneous coronary intervention. Eur Heart J 2010;31:2482-91.

3 Steg PG, Jolly SS, Mehta SR, Afzal R, Xavier D, Rupprecht HJ, et al. Low-dose vs standard-dose unfractionated heparin for percutaneous coronary intervention in acute coronary syndromes treated with fondaparinux: the FUTURA/OASIS-8 randomized trial. JAMA 2010;304:1339-49.

4 Brener SJ, Moliterno DJ, Lincoff AM, Steinhubl SR, Wolski KE, Topol EJ. Relationship between activated clotting time and ischemic or hemorrhagic complications: analysis of 4 recent randomized clinical trials of percutaneous coronary intervention. Circulation 2004;110:994-8.

5 Xiao Z, Theroux P. Platelet activation with unfractionated heparin at therapeutic concentrations and comparisons with a low-molecular-weight heparin and with a direct thrombin inhibitor. Circulation 1998;97:251-6.

6 Montalescot G, Bal-dit-Sollier C, Chibedi D, Collet JP, Soulat T, Dalby M, et al. Comparison of effects on markers of blood cell activation of enoxaparin, dalteparin, and unfractionated heparin in patients with unstable angina pectoris or non-ST-segment elevation acute myocardial infarction (the ARMADA study). Am J Cardiol 2003;91:925-30.

7 Smith SC Jr, Feldman TE, Hirshfeld JW Jr, Jacobs AK, Kern MJ, King SB 3rd, et al. ACC/AHA/SCAI 2005 guideline update for percutaneous coronary intervention: a report of the American College of Cardiology/American Heart Association Task Force on Practice Guidelines (ACC/AHA/SCAI Writing Committee to Update 2001 Guidelines for Percutaneous Coronary Intervention). Circulation 2006;113:e166-286.

8 Wijns W, Kolh P, Danchin N, Di Mario C, Falk V, Folliguet T, et al. Guidelines on myocardial revascularization: The Task Force on Myocardial Revascularization of the European Society of Cardiology (ESC) and the European Association for Cardio-Thoracic Surgery (EACTS). Eur Heart J 2010:31:2501-55.

9 Silvain J, Beygui F, Ankri A, Bellemain-Appaix A, Pena A, Barthelemy O, et al. Enoxaparin anticoagulation monitoring in the catheterization laboratory using a new bedside test. $J$ Am Coll Cardiol 2010;55:617-25

10 Montalescot G, Collet JP, Tanguy ML, Ankri A, Payot L, Dumaine R, et al. Anti-Xa activity relates to survival and efficacy in unselected acute coronary syndrome patients treated with enoxaparin. Circulation 2004:110:392-8.

11 Montalescot G, White HD, Gallo R, Cohen M, Steg PG, Aylward PE, et al. Enoxaparin versus unfractionated heparin in elective percutaneous coronary intervention. $N$ Engl $J$ Med 2006;355:1006-17.

12 Montalescot G, Gallo R, White HD, Cohen M, Steg PG, Aylward PE, et al. Enoxaparin versus unfractionated heparin in elective percutaneous coronary intervention 1-year results from the STEEPLE (SafeTy and efficacy of enoxaparin in percutaneous coronary intervention patients, an international randomized evaluation) trial. JACC CardiovasC Interv 2009;2:1083-91.

13 Montalescot G, Ellis SG, de Belder MA, Janssens L, Katz O, Pluta W, et al. Enoxaparin in primary and facilitated percutaneous coronary intervention. A formal prospective nonrandomized substudy of the FINESSE trial (Facilitated INtervention with Enhanced Reperfusion Speed to Stop Events). JACC Cardiovasc Interv 2010;3:203-12.

14 Montalescot G, Zeymer U, Silvain J, Boulanger B, Cohen M, Goldstein P, et al. Intravenous enoxaparin or unfractionated heparin in primary percutaneous coronary intervention for ST-elevation myocardial infarction: the international randomised open-label ATOLL trial. Lancet 2011;378:693-703.

15 Bertel O, Ramsay D, Wettstein T, Kurz DJ, Stettler I, Straumann E, et al. Intravenous enoxaparin versus unfractionated heparin in unselected patients undergoing percutaneous coronary interventions: the Zurich enoxaparin versus unfractionated heparin in $\mathrm{PCl}$ study (ZEUS). Eurolntervention 2010;6:407-12.

16 Brieger D, Collet JP, Silvain J, Landivier A, Barthelemy O, Beygui F, et al. Heparin or enoxaparin anticoagulation for primary percutaneous coronary intervention. Cathet Cardiovasc Interv 2011;77:182-90.

17 Diez JG, Medina HM, Cheong BY, O'Meallie L, Ferguson JJ. Safety of enoxaparin versus unfractionated heparin during percutaneous coronary intervention. Tex Heart Inst $J$ 2009;36:98-103

18 Drozd J, Opalinska E, Wojcik J, Madejczyk A. The use of enoxaparin during percutaneous coronary angioplasty in patients with stable angina. Kardiologia polska 2001;55:520.

19 Galeote G, Moreno R, Sanchez-Recalde A, Jimenez-Valero S, Calvo L, Rivero F, et al. [Enoxaparin vs. non-fractionated heparin in primary angioplasty of acute myocardial infarction]. Med Intensiva 2009;33:1-7.

20 Zeymer U, Gitt A, Junger C, Koeth O, Zahn R, Wienbergen H, et al. Clinical benefit of enoxaparin in patients with high-risk acute coronary syndromes without ST elevations in clinical practice. Am J Cardiol 2006;98:19-22.

21 Her SH, Seung KB, Yoon HJ, Kim DB, Shin DI, Lee JM, Kim PJ, et al. Prospective, randomized, preliminary clinical trial with low-molecular-weight heparin or unfractionated heparin as periprocedural anticoagulant during elective percutaneous coronary intervention. Korean Circ J 2006;36:573-7. 
22 Madan M, Radhakrishnan S, Reis M, Paradiso-Hardy FL, Godin-Edgecombe M, Sparling $\mathrm{C}$, et al. Comparison of enoxaparin versus heparin during elective percutaneous coronary intervention performed with either eptifibatide or tirofiban (the ACTION Trial). Am J Cardiol 2005:95:1295-301.

23 Bhatt DL, Lee BI, Casterella PJ, Pulsipher M, Rogers M, Cohen M, et al. Safety of concomitant therapy with eptifibatide and enoxaparin in patients undergoing percutaneous coronary intervention: results of the Coronary Revascularization Using Integrilin and Single bolus Enoxaparin Study. J Am Coll Cardiol 2003:41:20-5.

24 Galeote G, Hussein M, Sobrino N, Calvo L, Sanchez-Recalde A, Sobrino JA. [Use of a combination of enoxaparin or unfractionated heparin and abciximab during percutaneous coronary interventions: a randomized pilot study]. Rev Esp Cardiol 2002;55:1261-6.

25 Rabah MM, Premmereur J, Graham M, Fareed J, Hoppensteadt DA, Grines LL, et al. Usefulness of intravenous enoxaparin for percutaneous coronary intervention in stable angina pectoris. Am J Cardiol 1999;84:1391-5.

26 Dudek D, Bartus S, Zymek P, Legutko J, Rzeszutko L, Janion M, et al. Abciximab and enoxaparin administration during elective high risk PTCA in patients with more than 3 days of ticlopidine pretreatment. J Am Coll Cardiol 2000;35:91A.

27 Dudek D, Dabrowski M, Ochala A, Lesaik M, Wnek A, Bryniarski L, et al. Multicenter, prospective, double-blind randomized comparison of enoxaparin versus unfractionated heparin for percutaneous coronary interventions. Am J Cardiol 2000:86(suppl 8A):15i.

28 Li YJ, Rha SW, Chen KY, Poddar KL, Jin Z, Minami Y, et al. Low-molecular-weight heparin versus unfractionated heparin in acute ST-segment elevation myocardial infarction patients undergoing primary percutaneous coronary intervention with drug-eluting stents. Am Heart J 2010;159:684-90 e1.

29 Khoobiar S, Mejevoi N, Kaid K, Boiangiu C, Setty S, Tanwir A, et al. Primary percutaneous coronary intervention for ST-elevation myocardial infarction using an intravenous and subcutaneous enoxaparin low molecular weight heparin regimen. J Thromb Thrombolysis 2008;26:85-90.

30 Sabatine MS, Morrow DA, Montalescot G, Dellborg M, Leiva-Pons JL, Keltai M, et al. Angiographic and clinical outcomes in patients receiving low-molecular-weight heparin versus unfractionated heparin in ST-elevation myocardial infarction treated with fibrinolytics in the CLARITY-TIMI 28 Trial. Circulation 2005;112:3846-54.

31 White HD, Kleiman NS, Mahaffey KW, Lokhnygina Y, Pieper KS, Chiswell K, et al. Efficacy and safety of enoxaparin compared with unfractionated heparin in high-risk patients with non-ST-segment elevation acute coronary syndrome undergoing percutaneous coronary intervention in the Superior Yield of the New Strategy of Enoxaparin, Revascularization and Glycoprotein IIb/IIla Inhibitors (SYNERGY) trial. Am Heart J 2006;152:1042-50.

32 Dubois CL, Belmans A, Granger CB, Armstrong PW, Wallentin L, Fioretti PM, et al. Outcome of urgent and elective percutaneous coronary interventions after pharmacologic reperfusion with tenecteplase combined with unfractionated heparin, enoxaparin, or abciximab. J Am Coll Cardiol 2003;42:1178-85.

33 Zeymer U, Gitt A, Zahn R, Junger C, Bauer T, Heer T, et al. Efficacy and safety of enoxaparin in combination with and without GP Ilb/llla inhibitors in unselected patients with ST segment elevation myocardial infarction treated with primary percutaneous coronary intervention. Eurolntervention 2009:4:524-8.

34 Gibson CM, Murphy SA, Montalescot G, Morrow DA, Ardissino D, Cohen M, et al. Percutaneous coronary intervention in patients receiving enoxaparin or unfractionated heparin after fibrinolytic therapy for ST-segment elevation myocardial infarction in the ExTRACT-TIMI 25 trial. J Am Coll Cardiol 2007;49:2238-46.

35 Gibson CM, Morrow DA, Murphy SA, Palabrica TM, Jennings LK, Stone PH, et al. A randomized trial to evaluate the relative protection against post-percutaneous coronary intervention microvascular dysfunction, ischemia, and inflammation among antiplatelet and antithrombotic agents: the PROTECT-TIMI-30 trial. J Am Coll Cardiol 2006;47:2364-73.

36 Cohen M, Theroux P, Borzak S, Frey MJ, White HD, Van Mieghem W, et al. Randomized double-blind safety study of enoxaparin versus unfractionated heparin in patients with non-ST-segment elevation acute coronary syndromes treated with tirofiban and aspirin: the ACUTE II study. The Antithrombotic Combination Using Tirofiban and Enoxaparin. Am Heart J 2002;144:470-7.

37 Goodman S. Enoxaparin and glycoprotein IIb/Illa inhibition in non-ST-elevation acute coronary syndrome: insights from the INTERACT trial. Am Heart J 2005;149:S73-80.

38 Blazing MA, de Lemos JA, White HD, Fox KA, Verheugt FW, Ardissino D, et al. Safety and efficacy of enoxaparin vs unfractionated heparin in patients with non-ST-segmen elevation acute coronary syndromes who receive tirofiban and aspirin: a randomized controlled trial. JAMA 2004;292:55-64

39 Antman EM, McCabe CH, Gurfinkel EP, Turpie AG, Bernink PJ, Salein D, et al. Enoxaparin prevents death and cardiac ischemic events in unstable angina/non-Q-wave myocardial infarction. Results of the thrombolysis in myocardial infarction (TIMI) 11B trial. Circulation 1999;100:1593-601

40 Cohen M, Demers C, Gurfinkel EP, Turpie AG, Fromell GJ, Goodman S, et al. A comparison of low-molecular-weight heparin with unfractionated heparin for unstable coronary artery disease. Efficacy and Safety of Subcutaneous Enoxaparin in Non-Q-Wave Coronary Events Study Group. N Engl J Med 1997;337:447-52.

41 Danchin N, Collet J, Marco J. Use of low molecular weight heparin is associated with mproved in-hospital survival of ST-elevation myocardial infarction patients who receive reperfusion therapy: results from the nationwide French FAST-MI registry. ACC Scientific Sessions: Mar 24-27, 2007: New Orleans, LA. 2007.

42 Ferguson JJ, Califf RM, Antman EM, Cohen M, Grines CL, Goodman S, et al. Enoxaparin vs unfractionated heparin in high-risk patients with non-ST-segment elevation acute coronary syndromes managed with an intended early invasive strategy: primary results of the SYNERGY randomized trial. JAMA 2004;292:45-54.

43 Zeymer U, Gitt A, Junger C, Bauer T, Heer T, Koeth O, et al. Efficacy and safety of enoxaparin in unselected patients with ST-segment elevation myocardial infarction. Thromb Haemost 2008:99:150-4.

44 Karsch KR, Preisack MB, Baildon R, Eschenfelder V, Foley D, Garcia EJ, et al. Low molecular weight heparin (reviparin) in percutaneous transluminal coronary angioplasty. Results of a randomized, double-blind, unfractionated heparin and placebo-controlled, multicenter trial (REDUCE trial). Reduction of Restenosis After PTCA, Early Administration of Reviparin in a Double-Blind Unfractionated Heparin and Placebo-Controlled Evaluation. J Am Coll Cardiol 1996;28:1437-43.

45 Natarajan MK, Velianou JL, Turpie AG, Mehta SR, Raco D, Goodhart DM, et al. A randomized pilot study of dalteparin versus unfractionated heparin during percutaneous coronary interventions. Am Heart J 2006;151:175.
46 Cucherat M, Boissel JP, Leizorovicz A, Haugh MC. EasyMA: a program for the meta-analysis of clinical trials. Comput Methods Programs Biomed 1997:53:187-90.

47 Clarke M. The Handbook for Systematic Reviews of Interventions. Version 4.2.0. Cochrane Collaboration, 2003

48 Egger M, Smith GD, Phillips AN. Meta-analysis: principles and procedures. BMJ 1997;315:1533-7.

49 Sanchez-Pena P, Hulot JS, Urien S, Ankri A, Collet JP, Choussat R, et al. Anti-factor Xa kinetics after intravenous enoxaparin in patients undergoing percutaneous coronary intervention: a population model analysis. Br J Clin Pharmacol 2005;60:364-73.

50 Collet JP, Montalescot G, Golmard JL, Tanguy ML, Ankri A, Choussat R, et al. Subcutaneous enoxaparin with early invasive strategy in patients with acute coronary syndromes. Am Heart J 2004;147:655-61.

51 Choussat R, Montalescot G, Collet JP, Vicaut E, Ankri A, Gallois V, et al. A unique, low dose of intravenous enoxaparin in elective percutaneous coronary intervention. $J \mathrm{Am} \mathrm{Coll}$ Cardiol 2002:40:1943-50.

52 Silvain J, Pena A, Cayla G, Brieger D, Bellemain-Appaix A, Chastre T, et al. Impact of red blood cell transfusion on platelet activation and aggregation in healthy volunteers: results of the TRANSFUSION study. Eur Heart J 2010;31:2816-21.

53 Rao SV, Eikelboom JA, Granger CB, Harrington RA, Califf RM, Bassand JP. Bleeding and blood transfusion issues in patients with non-ST-segment elevation acute coronary syndromes. Eur Heart J 2007;28:1193-204.

54 Lincoff AM, Bittl JA, Harrington RA, Feit F, Kleiman NS, Jackman JD, et al. Bivalirudin and provisional glycoprotein Ilb/llla blockade compared with heparin and planned glycoprotein IIb/Illa blockade during percutaneous coronary intervention: REPLACE-2 randomized trial. JAMA 2003;289:853-63.

55 Stone GW, McLaurin BT, Cox DA, Bertrand ME, Lincoff AM, Moses JW, et al. Bivalirudin for patients with acute coronary syndromes. N Engl J Med 2006;355:2203-16.

56 Stone GW, Witzenbichler B, Guagliumi G, Peruga JZ, Brodie BR, Dudek D, et al. Bivalirudin during primary PCl in acute myocardial infarction. N Engl J Med 2008;358:2218-30.

57 Doll JA, Nikolsky E, Stone GW, Mehran R, Lincoff AM, Caixeta A, et al. Outcomes of patients with coronary artery perforation complicating percutaneous coronary intervention and correlations with the type of adjunctive antithrombotic therapy: pooled analysis from REPLACE-2, ACUITY, and HORIZONS-AMI trials. J Interv Cardiol 2009;22:453-9.

58 Kastrati A, Neumann FJ, Mehilli J, Byrne RA, lijima R, Buttner HJ, et al. Bivalirudin versus unfractionated heparin during percutaneous coronary intervention. $N$ Engl $J$ Med 2008;359:688-96

59 Schulz S, Mehilli J, Neumann FJ, Schuster T, Massberg S, Valina C, et al. ISAR-REACT $3 \mathrm{~A}$ : a study of reduced dose of unfractionated heparin in biomarker negative patients undergoing percutaneous coronary intervention. Eur Heart J 2010;31:2482-91.

60 Schulz S, Mehilli J, Ndrepepa G, Neumann FJ, Birkmeier KA, Kufner S, et al. Bivalirudin vs. unfractionated heparin during percutaneous coronary interventions in patients with stable and unstable angina pectoris: 1 -year results of the ISAR-REACT 3 trial. Eur Heart $J$ 2010;31:582-7.

61 De Luca G, Cassetti E, Verdoia M, Marino P. Bivalirudin as compared to unfractionated heparin among patients undergoing coronary angioplasty: a meta-analyis of randomised trials. Thromb Haemost 2009:102:428-36.

62 Navarese EP, De Luca G, Castriota F, Kozinski M, Gurbel PA, Gibson CM, et al. Low-molecular-weight heparins vs. unfractionated heparin in the setting of percutaneous coronary intervention for ST-elevation myocardial infarction: a meta-analysis. J Thromb Haemost 2011;9:1902-15.

63 Mehta SR, Granger CB, Eikelboom JW, Bassand JP, Wallentin L, Faxon DP, et al. Efficacy and safety of fondaparinux versus enoxaparin in patients with acute coronary syndromes undergoing percutaneous coronary intervention: results from the OASIS- 5 trial. J Am Coll Cardiol 2007;50:1742-51

64 Yusuf S, Mehta SR, Chrolavicius S, Afzal R, Pogue J, Granger CB, et al. Effects of fondaparinux on mortality and reinfarction in patients with acute ST-segment elevation myocardial infarction: the OASIS-6 randomized trial. JAMA 2006;295:1519-30

65 Mehta SR, Steg PG, Granger CB, Bassand JP, Faxon DP, Weitz JI, et al. Randomized, blinded trial comparing fondaparinux with unfractionated heparin in patients undergoing contemporary percutaneous coronary intervention: Arixtra Study in Percutaneous Coronary Intervention: a Randomized Evaluation (ASPIRE) Pilot Trial. Circulation 2005;111:1390-7.

66 Mehta SR, Boden WE, Eikelboom JW, Flather M, Steg PG, Avezum A, et al. Antithrombotic therapy with fondaparinux in relation to interventional management strategy in patients with ST- and non-ST-segment elevation acute coronary syndromes: an individual patient-level combined analysis of the Fifth and Sixth Organization to Assess Strategies in Ischemic Syndromes (OASIS 5 and 6) randomized trials. Circulation 2008;118:2038-46.

67 Dumaine R, Borentain M, Bertel O, Bode C, Gallo R, White HD, et al. Intravenous low-molecular-weight heparins compared with unfractionated heparin in percutaneous coronary intervention: quantitative review of randomized trials. Arch Intern Med 2007;167:2423-30.

68 Romagnoli E. The Radial versus Femoral Randomized Investigation in ST Elevation Acute Coronary Syndrome (RIFLE STEACS) trial. Oral presentation at the 23rd annual Transcatheter Cardiovascular Therapeutics scientific symposium. San Francisco, 10 Nov 2011.

69 Jolly SS, Yusuf S, Cairns J, Niemelä K, Xavier D, Widimsky P et al. Radial versus femoral access for coronary angiography and intervention in patients with acute coronary syndromes (RIVAL): a randomised, parallel group, multicentre trial. Lancet 2011;377:1409-20

\section{Accepted: 19 January 2012}

\section{Cite this as: BMJ 2012;344:e553}

This is an open-access article distributed under the terms of the Creative Commons Attribution Non-commercial License, which permits use, distribution, and reproduction in any medium, provided the original work is properly cited, the use is non commercial and is otherwise in compliance with the license. See: http://creativecommons.org/licenses/bync/2.0/ and http://creativecommons.org/licenses/by-nc/2.0/legalcode. 


\section{Tables}

\begin{tabular}{|c|c|c|c|c|c|}
\hline \multicolumn{6}{|c|}{ Table 1| Description of studies included in meta-analysis } \\
\hline Study & Journal & $\begin{array}{l}\text { No of patients in } \\
\text { enoxaparin/unfractionated } \\
\text { heparin groups }\end{array}$ & $\begin{array}{l}\text { Study design (quality score*or } \\
\text { risk of bias) }\end{array}$ & $\begin{array}{l}\text { Study population/PCI } \\
\text { setting }\end{array}$ & Follow-up \\
\hline ATOLL $2011^{14}$ & Lancet & $450 / 460$ & $\begin{array}{l}\text { Randomised controlled trial (low } \\
\text { risk) }\end{array}$ & Primary PCI (STEMI) & 1 month \\
\hline Brieger et al $2011^{16}$ & $\begin{array}{l}\text { Catheter Cardiovascular } \\
\text { Intervention }\end{array}$ & $346 / 234$ & Registry (8/9) & Primary PCI (STEMI) & 1 month \\
\hline Li et al $2010^{28}$ & American Heart Journal & $1531 / 1841$ & Registry (9/9) & Primary PCI (STEMI) & 8 months \\
\hline FINESSE Enox $2010^{13}$ & $\begin{array}{l}\text { JACC. Cardiovascular } \\
\text { Interventions }\end{array}$ & $759 / 1693$ & $\begin{array}{l}\text { Prospective substudy of } \\
\text { randomised controlled trial (9/9) }\end{array}$ & $\begin{array}{l}\text { Primary PCI (STEMI) with } \\
33 \% \text { of patients receiving } \\
\text { half dose thrombolysis }\end{array}$ & 3 months \\
\hline Galeote et al $2009^{19}$ & Medicina Intensiva & $91 / 100$ & Registry (6/9) & Primary PCI (STEMI) & In-hospital \\
\hline Khoobiar et al $2008^{29}$ & $\begin{array}{l}\text { Journal of Thrombosis and } \\
\text { Thrombolysis }\end{array}$ & $39 / 44$ & Registry (6/9) & Primary PCI (STEMI) & 15 months \\
\hline Zeymer et al $2008^{43}$ & Eurointervention & $374 / 2281$ & Registry (9/9) & Primary PCI (STEMI) & In-hospital \\
\hline $\begin{array}{l}\text { ExTRACT-TIMI } 25 \\
2007^{34}\end{array}$ & $\begin{array}{l}\text { Journal of the American } \\
\text { College of Cardiology }\end{array}$ & 2272/2404 & $\begin{array}{l}\text { Retrospective analysis of } \\
\text { randomised controlled trial (9/9) }\end{array}$ & $\begin{array}{l}\text { Post-fibrinolysis PCl } \\
\text { (STEMI) }\end{array}$ & 1 month \\
\hline $\begin{array}{l}\text { CLARITY-TIMI } 28 \\
2005^{30}\end{array}$ & Circulation & $1429 / 1431$ & $\begin{array}{l}\text { Retrospective analysis of } \\
\text { randomised controlled trial (9/9) }\end{array}$ & $\begin{array}{l}\text { Post-fibrinolysis PCI } \\
\text { (STEMI) }\end{array}$ & 1 month \\
\hline ASSENT-3 $2003^{32}$ & $\begin{array}{l}\text { Journal of the American } \\
\text { College of Cardiology }\end{array}$ & $590 / 624$ & $\begin{array}{l}\text { Retrospective analysis of } \\
\text { randomised controlled trial (9/9) }\end{array}$ & $\begin{array}{l}\text { Post-fibrinolysis PCI } \\
\text { (STEMI) }\end{array}$ & 12 months \\
\hline ZEUS $2010^{15}$ & Eurointervention & $436 / 440$ & $\begin{array}{l}\text { Randomised controlled trial (low } \\
\text { risk) }\end{array}$ & Elective or urgent $\mathrm{PCI}$ & 1 month \\
\hline Diez et al $2009^{17}$ & Texas Heart Institute Journal & $222 / 271$ & Registry (8/9) & Elective or urgent $\mathrm{PCI}$ & In-hospital \\
\hline Zeymer et al $2006^{20}$ & $\begin{array}{l}\text { American Journal of } \\
\text { Cardiology }\end{array}$ & $339 / 994$ & Registry (8/9) & Early PCI & In-hospital \\
\hline STEEPLE $2006^{11}$ & $\begin{array}{l}\text { New England Journal of } \\
\text { Medicine }\end{array}$ & 2298 (2 doses)/1230 & $\begin{array}{l}\text { Randomised controlled trial (low } \\
\text { risk) }\end{array}$ & Elective PCI & 1 month \\
\hline SYNERGY $2006^{31}$ & American Heart Journal & $2028 / 2293$ & $\begin{array}{l}\text { Retrospective analysis of } \\
\text { randomised controlled trial (9/9) }\end{array}$ & Elective or urgent $\mathrm{PCl}$ & 1 month \\
\hline Her et al $2006^{21}$ & Korean Circulation Journal & $68 / 71$ & $\begin{array}{l}\text { Randomised controlled trial } \\
\text { (unclear risk) }\end{array}$ & Elective PCl & 1 month \\
\hline ACTION $2005^{22}$ & $\begin{array}{l}\text { American Journal of } \\
\text { Cardiology }\end{array}$ & $100 / 100$ & $\begin{array}{l}\text { Randomised controlled trial (low } \\
\text { risk) }\end{array}$ & Elective $\mathrm{PCl}$ & 1 month \\
\hline CRUISE $2003^{23}$ & $\begin{array}{l}\text { Journal of the American } \\
\text { College of Cardiology }\end{array}$ & $129 / 132$ & $\begin{array}{l}\text { Randomised controlled trial (low } \\
\text { risk) }\end{array}$ & Elective or urgent $\mathrm{PCl}$ & 1 month \\
\hline Galeote et al $2002^{24}$ & $\begin{array}{l}\text { Revista Espanola de } \\
\text { Cardiologia }\end{array}$ & $50 / 49$ & $\begin{array}{l}\text { Randomised controlled trial } \\
\text { (unclear risk) }\end{array}$ & Elective or urgent $\mathrm{PCl}$ & In-hospital \\
\hline Drozd et al $2001^{18}$ & Kardiologia Polska & $50 / 50$ & $\begin{array}{l}\text { Randomised controlled trial } \\
\text { (unclear risk) }\end{array}$ & Elective $\mathrm{PCl}$ & 1 month \\
\hline Dudek et al $2000^{27}$ & $\begin{array}{l}\text { American Journal of } \\
\text { Cardiology }\end{array}$ & $200 / 200$ & $\begin{array}{l}\text { Randomised controlled trial (low } \\
\text { risk) }\end{array}$ & Elective or urgent $\mathrm{PCl}$ & In-hospital \\
\hline Dudek et al $2000^{26}$ & $\begin{array}{l}\text { Journal of the American } \\
\text { College of Cardiology }\end{array}$ & $112(2$ doses $) / 50$ & $\begin{array}{l}\text { Randomised controlled trial } \\
\text { (unclear risk) }\end{array}$ & Elective $\mathrm{PCl}$ & In-hospital \\
\hline Rabah et al $1999^{25}$ & $\begin{array}{l}\text { American Journal of } \\
\text { Cardiology }\end{array}$ & $30 / 30$ & $\begin{array}{l}\text { Randomised controlled trial (low } \\
\text { risk) }\end{array}$ & Elective $\mathrm{PCl}$ & 1 month \\
\hline
\end{tabular}

$\mathrm{PCl}=$ percutaneous coronary intervention; STEMI=ST elevation myocardial infarction.

*Non-randomised controlled trials. 


\begin{tabular}{|c|c|c|c|c|c|c|c|}
\hline \multirow[b]{2}{*}{ Subgroup } & \multirow[b]{2}{*}{$\begin{array}{l}\text { No of } \\
\text { studies }\end{array}$} & \multirow[b]{2}{*}{ No of patients } & \multicolumn{2}{|c|}{ No of deaths/No in group } & \multirow[b]{2}{*}{ Relative risk (95\% Cl) } & \multicolumn{2}{|c|}{$P$ values } \\
\hline & & & Enoxaparin group & $\begin{array}{l}\text { Unfractionated heparin } \\
\text { group }\end{array}$ & & Overall & $\begin{array}{c}\text { For } \\
\text { heterogeneity }\end{array}$ \\
\hline Overall & 23 & 30966 & 278/13 943 & $622 / 17023$ & $0.66(0.57$ to 0.76$)$ & $<0.001$ & 0.46 \\
\hline $\begin{array}{l}\text { Published (full length } \\
\text { report) }\end{array}$ & 21 & 30404 & $278 / 13631$ & $621 / 16773$ & 0.66 (0.56 to 0.77$)$ & $<0.001$ & 0.56 \\
\hline Large size $(\geq 500)$ & 12 & 28778 & $275 / 12852$ & $615 / 15923$ & $0.65(0.52$ to 0.81$)$ & $<0.001$ & 0.43 \\
\hline Small size $(<500)$ & 11 & 2188 & $3 / 1091$ & $7 / 1097$ & $0.59(0.20$ to 1.78$)$ & 0.35 & 0.46 \\
\hline Patients with STEMI & 10 & 18993 & $237 / 7881$ & $557 / 11112$ & $0.62(0.48$ to 0.78$)$ & $<0.001$ & 0.52 \\
\hline High quality studies: $\mathrm{RCT}^{*}$ & 16 & 22259 & $211 / 11001$ & $325 / 11258$ & $0.78(0.66$ to 0.93$)$ & 0.006 & 0.97 \\
\hline $\begin{array}{l}\text { Low quality studies: } \\
\text { registries }\end{array}$ & 7 & 8707 & $67 / 2943$ & $297 / 5765$ & $0.43(0.33$ to 0.57$)$ & $<0.001$ & 0.86 \\
\hline Subcutaneous enoxaparin & $6 \dagger$ & 16527 & $197 / 7889$ & $314 / 8638$ & $0.70(0.53$ to 0.94$)$ & 0.017 & 0.57 \\
\hline Intravenous enoxaparin & $15 \dagger$ & 10451 & $74 / 5341$ & $151 / 5110$ & 0.66 (0.50 to 0.88$)$ & 0.004 & 0.99 \\
\hline
\end{tabular}

STEMI=ST elevation myocardial infarction; RCT=randomised controlled trial. *Including substudies of RCTs.

†Two studies did not mention mode in which drug was administered. ${ }^{2033}$ 


\begin{tabular}{|c|c|c|c|c|c|c|c|}
\hline \multirow[b]{2}{*}{ Subgroup } & \multirow[b]{2}{*}{$\begin{array}{l}\text { No of } \\
\text { studies }\end{array}$} & \multirow[b]{2}{*}{ No of patients } & \multicolumn{2}{|c|}{ No with major bleeding/No in group } & \multirow[b]{2}{*}{ Relative risk $(95 \% \mathrm{Cl})$} & \multicolumn{2}{|c|}{$P$ values } \\
\hline & & & Enoxaparin group & $\begin{array}{l}\text { Unfractionated heparin } \\
\text { group }\end{array}$ & & Overall & $\begin{array}{c}\text { For } \\
\text { heterogeneity }\end{array}$ \\
\hline Overall & $22^{*}$ & 30775 & $295 / 13852$ & $564 / 16923$ & $0.80(0.68$ to 0.95$)$ & 0.009 & 0.58 \\
\hline $\begin{array}{l}\text { Published (full length } \\
\text { report) }\end{array}$ & 20 & 30213 & $295 / 13540$ & $564 / 16673$ & 0.80 (0.66 to 0.96$)$ & 0.022 & 0.62 \\
\hline Large size $(\geq 500)$ & 12 & 28778 & $288 / 12852$ & $549 / 15926$ & $0.80(0.50$ to 0.99$)$ & 0.041 & 0.55 \\
\hline Small size $(<500)$ & 10 & 1997 & $7 / 1000$ & $15 / 997$ & $0.62(0.27$ to 1.42$)$ & 0.26 & 0.98 \\
\hline Patients with STEMI & 9 & 18802 & $170 / 7790$ & $384 / 11012$ & $0.80(0.66$ to 0.97$)$ & 0.026 & 0.44 \\
\hline High quality studies: RCTs† & 16 & 22259 & $226 / 11001$ & $299 / 11258$ & $0.83(0.66$ to 1.04$)$ & 0.11 & 0.70 \\
\hline $\begin{array}{l}\text { Low quality studies: registry } \\
\text { based }\end{array}$ & 7 & 8516 & $69 / 2851$ & $265 / 5665$ & $0.73(0.55$ to 0.96$)$ & 0.026 & 0.80 \\
\hline Subcutaneous enoxaparin & 6 & 16527 & $149 / 7889$ & $154 / 8638$ & $1.04(0.80$ to 1.35$)$ & 0.75 & 0.43 \\
\hline Intravenous enoxaparin & 14 & 10260 & $114 / 5250$ & $185 / 5010$ & 0.66 (0.52 to 0.83$)$ & $<0.001$ & 0.90 \\
\hline
\end{tabular}

$\mathrm{RCT}=$ randomised controlled trial; STEMI=ST elevation myocardial infarction.

*One study did not report major bleeding in both groups and was excluded from analysis. ${ }^{24}$ 


\section{Figures}

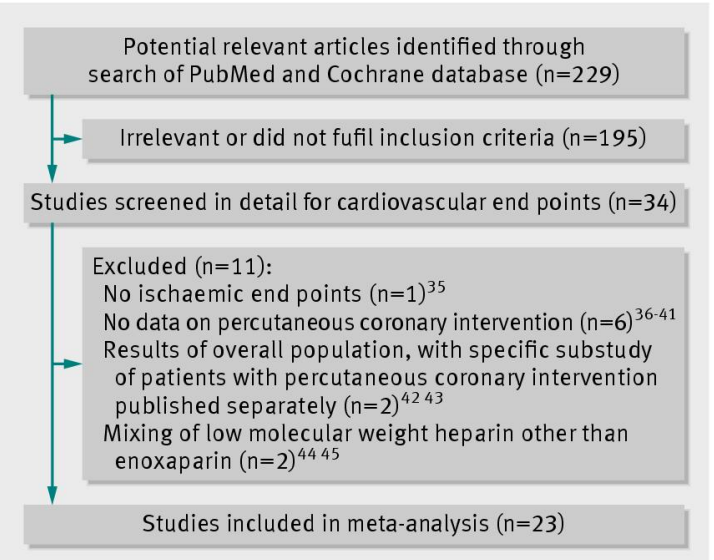

Fig 1 Flow of studies through review

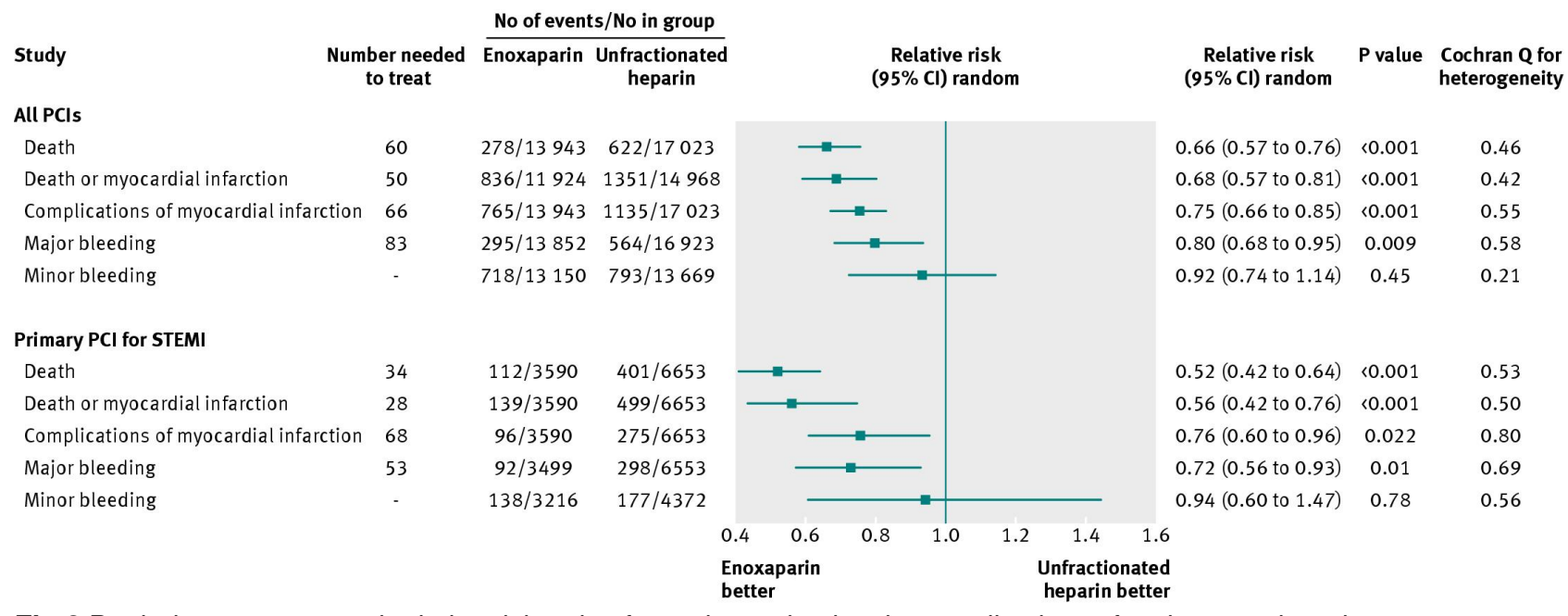

Fig 2 Pooled event rates and relative risk ratios for major end points in overall cohort of patients undergoing percutaneous coronary intervention $(\mathrm{PCl})$ and in subgroup of patients undergoing primary percutaneous coronary intervention. STEMI=ST elevation myocardial infarction 
Study

Patients with STEMI

ATOLL ${ }^{14}$

Brieger et $\mathrm{al}^{16}$

Li et al ${ }^{28}$

FINESSE Enox ${ }^{13}$

Galeote et a ${ }^{19}$

Khoobiar et al ${ }^{29}$

Zeymer et al ${ }^{43}$

All primary PCls

EXTRACT-TIMI $25^{34}$

CLARITY-TIMI $28^{30}$

ASSENT-3 PCI ${ }^{32}$

All secondary $\mathrm{PCls}$

All patients with STEMI

Patients with non-STE ACS and stable patients ZEUS $^{15}$

Diez et al ${ }^{17}$

Zeymer et $\mathrm{al}^{20}$

STEEPLE ${ }^{11}$

SYNERGY PCl ${ }^{31}$

Her et $\mathrm{al}^{21}$

ACTION $^{22}$

CRUISE $^{23}$

Galeote et al ${ }^{24}$

Drozd et al ${ }^{18}$

Dudek et al ${ }^{27}$

Dudek et al ${ }^{26}$

Rabah et a ${ }^{25}$

All patients with non-STE ACS and stable patients

Overall
No of events/No in group

Enoxaparin Unfractionated

heparin

Relative risk
$(95 \% \mathrm{Cl})$ random

$17 / 450 \quad 29 / 460$

$13 / 346 \quad 18 / 234$

45/1531 116/1841

$29 / 759 \quad 95 / 1693$

$1 / 91 \quad 3 / 100$

$1 / 39 \quad 3 / 44$

$6 / 374 \quad 137 / 2281$

$112 / 3590 \quad 401 / 6653$

$66 / 2272 \quad 71 / 2404$

$44 / 1429 \quad 68 / 1431$

$15 / 590 \quad 17 / 624$

$125 / 4291 \quad 156 / 4459$

$237 / 7881 \quad 557 / 11112$

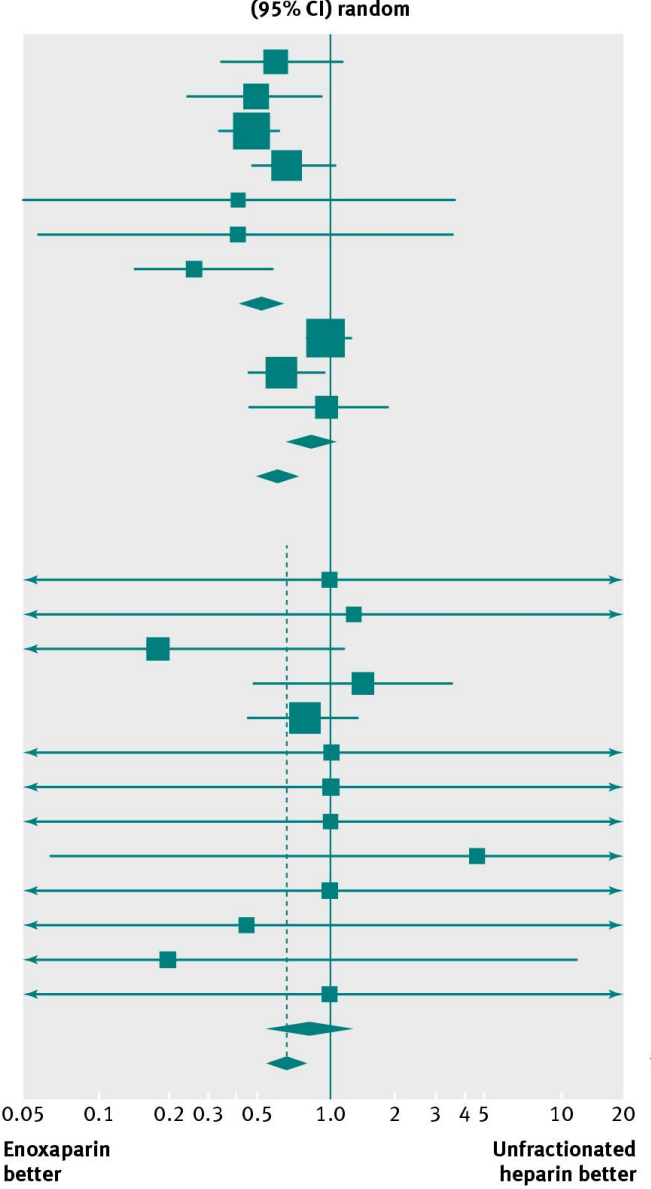

Weight Relative risk

(\%) $\quad(95 \% \mathrm{Cl})$ random

$6.380 .60(0.34$ to 1.08$)$

$4.55 \quad 0.49(0.25$ to 0.98$)$

$18.97 \quad 0.47$ (0.33 to 0.66$)$

$13.08 \quad 0.68$ ( 0.46 to 1.03$)$

0.520 .42 (0.05 to 3.26 )

$0.53 \quad 0.43$ (0.06 to 3.26 )

3.410 .28 (0.13 to 0.61$)$

$47.44 \quad 0.52$ (0.42 to 0.64$)$

$19.80 \quad 0.98$ (0.71 to 1.37$)$

15.610 .65 (0.45 to 0.94$)$

4.650 .93 (0.47 to 1.84$)$

$40.06 \quad 0.83$ (0.66 to 1.05$)$

$87.50 \quad 0.62$ (0.48 to 0.79 )

$0.07 \quad 1.01$ (0.00 to 257)

$0.07 \quad 1.22$ (0.00 to 311 )

$0.07 \quad 0.18$ (0.03 to 1.10$)$

$2.11 \quad 1.35$ (0.49 to 3.70 )

$8.93 \quad 0.76(0.46$ to 1.24$)$

$0.07 \quad 1.04$ (0.00 to 265 )

$0.07 \quad 1.00$ (0.00 to 254)

$0.07 \quad 1.02$ (0.00 to 260 )

$0.12 \quad 4.90(0.07$ to 353$)$

$0.07 \quad 1.00(0.00$ to 252$)$

$0.07 \quad 0.45$ (0.00 to 114 )

0.120 .20 (0.00 to 14.6$)$

$0.07 \quad 1.00$ (0.00 to 250 )

$12.50 \quad 0.78(0.52$ to 1.12$)$

$100.00 \quad 0.66$ (0.57 to 0.76 )

$41 / 6062 \quad 65 / 5911$

$278 / 13943 \quad 622 / 17023$

Fig 3 All cause mortality in patients undergoing percutaneous coronary intervention (PCI) treated with enoxaparin or unfractionated heparin. STEMI=ST elevation myocardial infarction; non-STE ACS=non-ST elevation acute coronary syndrome 
Study

Patients with STEMI

ATOLL ${ }^{14}$

Brieger et $\mathrm{al}^{16}$

Li et al ${ }^{28}$

FINESSE Enox ${ }^{13}$

Khoobiar et al ${ }^{29}$

Zeymer et $\mathrm{al}^{43}$

All primary $\mathrm{PCl}$

CLARITY-TIMI $28^{30}$

ASSENT-3 PC| $\left.\right|^{32}$

All secondary $\mathrm{PCls}$

All patients with STEMI

Patients with non-STE ACS and stable patients

ZEUS ${ }^{15}$

Diez et $\mathrm{al}^{17}$

Zeymer et $\mathrm{a}^{20}$

STEEPLE ${ }^{11}$

SYNERGY PCl ${ }^{31}$

Her et $\mathrm{al}^{21}$

ACTION ${ }^{22}$

CRUISE $^{23}$

Galeote et $\mathrm{al}^{24}$

Drozd et al ${ }^{18}$

Dudek et $\mathrm{al}^{27}$

Rabah et al ${ }^{25}$

All patients with non-STE ACS and stable patients

Overall
EXTRACT-TIMI $25^{34}$

Dudek et $\mathrm{al}^{26}$
No of events/No in group

Enoxaparin Unfractionated

heparin

Relative risk

$(95 \% \mathrm{Cl})$ random

$\begin{array}{cc}20 / 450 & 22 / 460 \\ 27 / 346 & 21 / 234 \\ 8 / 1531 & 11 / 1841 \\ 21 / 759 & 78 / 1693 \\ 0 / 39 & 2 / 44 \\ 16 / 374 & 164 / 2281 \\ 92 / 3499 & 298 / 6553 \\ 32 / 2272 & 39 / 2404 \\ 23 / 1429 & 31 / 1431 \\ 23 / 590 & 16 / 624 \\ 78 / 4291 & 86 / 4459 \\ 170 / 7790 & 384 / 11012\end{array}$

$170 / 7790 \quad 384 / 11012$

$\begin{array}{cc}11 / 436 & 17 / 440 \\ 2 / 222 & 6 / 271 \\ 16 / 339 & 61 / 994 \\ 28 / 2298 & 34 / 1230 \\ 63 / 2028 & 55 / 2294 \\ 0 / 68 & 0 / 71 \\ 0 / 100 & 0 / 100 \\ 3 / 129 & 2 / 132 \\ 1 / 50 & 4 / 49 \\ 0 / 50 & 0 / 50 \\ 0 / 112 & 0 / 50 \\ 0 / 200 & 0 / 200 \\ 1 / 30 & 1 / 30 \\ 125 / 6062 & 180 / 5911 \\ 295 / 13852 & 564 / 16923\end{array}$

\section{$\begin{array}{lr}0.05 & 0.1 \\ \text { Enoxaparin }\end{array}$}

Enoxaparin
better

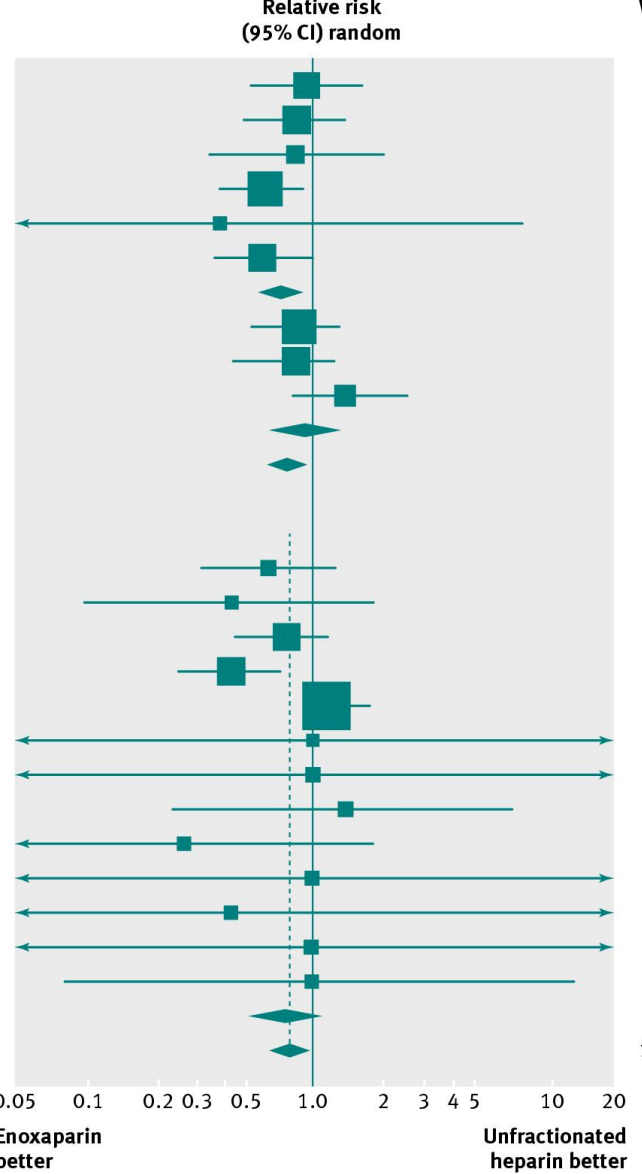

Weight Relative risk

(\%) $\quad(95 \% \mathrm{Cl})$ random

$6.680 .93(0.52$ to 1.67$)$

$7.67 \quad 0.87$ (0.50 to 1.49 )

$3.10 \quad 0.88$ (0.36 to 2.16 )

9.690 .61 (0.38 to 0.97 )

$0.16 \quad 0.13$ (0.00 to 7.63 )

8.870 .60 ( 0.37 to 0.99$)$

$36.17 \quad 0.72$ (0.56 to 0.93 )

10.020 .87 (0.55 to 1.38$)$

$7.93 \quad 0.75$ (0.44 to 1.27 )

$6.01 \quad 1.51$ (0.81 to 2.82 )

23.960 .96 (0.65 to 1.41 )

60.130 .80 (0.66 to 0.97 )

$4.420 .66(0.31$ to 1.38$)$

1.130 .44 (0.10 to 2.00 )

7.910 .78 (0.46 to 1.32 )

$9.00 \quad 0.44(0.27$ to 0.72$)$

14.961 .29 (0.91 to 1.85$)$

$0.09 \quad 1.04$ (0.00 to 265$)$

$0.09 \quad 1.00(0.00$ to 254$)$

0.921 .48 (0.27 to 7.95$)$

$0.68 \quad 0.29$ (0.04 to 2.04$)$

$0.09 \quad 1.00$ (0.00 to 252)

$0.09 \quad 0.45$ (0.00 to 114$)$

$0.09 \quad 1.00$ (0.00 to 255 )

$0.44 \quad 1.00$ (0.09 to 11.3 )

$39.87 \quad 0.77$ (0.55 to 1.05$)$

$100.00 \quad 0.80$ (0.68 to 0.95$)$

heparin better

Fig 4 Major bleeding in patients undergoing percutaneous coronary intervention $(\mathrm{PCl})$ treated with enoxaparin or unfractionated heparin. STEMI=ST elevation myocardial infarction; non-STE ACS=non-ST elevation acute coronary syndrome 